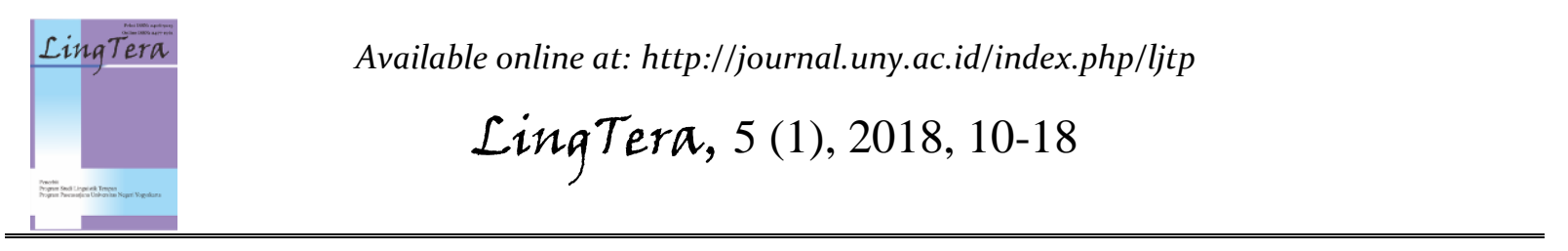

\title{
Language attitude of Indonesian undergraduate students towards English at English Education Department
}

\author{
Setyo Wati \\ Universitas Perjuangan Tasikmalaya. Jalan Pembela Tanah Air 177, Kahuripan, Tawang, \\ Tasikmalaya, Jawa Barat 46115, Indonesia \\ * Corresponding Author. Email: anasetyowati33@gmail.com \\ Received: 20 May 2016; Revised: 16 April 2018; Accepted: 14 May 2018
}

\begin{abstract}
This research aims to: (1) describe the language attitudes of undergraduate students of English Education Department of Surakarta Muhamamadiyah University toward English language in terms of their behavioural, cognitive, and affective aspects; and (2) investigate the differences in language attitudes of undergraduate students towards English across gender and length of study at English education department of Surakarta Muhammadiyah University. This research employed a mixed method research design to collect, analyse and to mix both quantitative and qualitative data in a single study. Researcher used theory in a quantitative study to provide an explanation about the relationship among variables in the study. Thus, it is essential to have grounding in the qualitative study. The results of the study are as follows. The undergraduate students have different language attitudes, in terms of cognitive, behavioural, and affective aspects of language attitudes towards English. There is a statistic difference in the undergraduate students' language attitudes towards English across gender. The attitudes of male undergraduate students towards English are higher than that of female ones indicating more positive attitudes towards English. It means that there is a rejection of the null hypothesis, because there is a significant difference between male and female undergraduate students' attitudes towards English. There is a difference among the three groups in terms of length of English study. The freshman group showed slightly higher language attitudes compared with those of the other two groups.
\end{abstract}

Keywords: language attitudes, undergraduate students

How to Cite: Wati, S. (2018). Language attitude of undergraduate students towards English at English Education Department. LingTera, 5(1), 10-18. doi:http://dx.doi.org/10.21831/lt.v5i1.8583

http://dx.doi.org/10.21831/lt.v5i1.8583

\section{INTRODUCTION}

English is a lingua franca since many people from all over the world speak English. Wherever going a travel in a foreign city, people will see English signs and advertisements. It means that English language becomes one of the most frequently spoken languages in the world today. Jenkins (2014) puts forward the view that English as a Lingua Franca (ELF) refers to the use of English as a contact language between people who have different first languages, including native English speakers. According to the United Nations Educational, Scientific, and Cultural Organization (UNESCO) in UNESCO Education Position Paper published in Paris in 2003, a lingua franca as a language used routinely by people, whose mother tongues are different, is used to facilitate communication between them. Hence, to bridge communication between other different tongues from different countries, English becomes as a lingua franca which is an international language.

As an international language, English becomes a prestigious position in many countries, including in Indonesia. This language becomes one of popular languages to be studied in Indonesia since English becomes a choice as a foreign language which has to be studied. Therefore, there is an increasing focus on English teaching learning at all levels in Indonesia, including each school level until university level in Indonesia. As one of compulsory subjects taught in Indonesia, English learning process now extends through primary school, junior high school, senior high school, and university, covering span of about 12 years. As stated by Yusny (2013), on his study to render an analysis on how the impression of linguistic imperialism 
of English in the era of globalization would affect Language Teaching of English in Indonesian context. English has been getting considered very important compared to other subjects in Indonesian education system. Hence, English has been taught in Indonesian schools as a compulsory subject of school until university levels. This is confirmed by the fact that English is tested the Indonesian national examination.

Since English has become a noteworthy part of the nation's institutions in Indonesia, there has been an increasing popularity of English language learning. As stated by Lauder (2008, p.13), English is one of a number of foreign languages which have been used in communication, including Arabic, English, Dutch, German, French, Japanese, and currently Chinese. Every foreign language which is used in Indonesia has every single important purpose for society. English language later grows impressively in Asian countries and Indonesia is a part of the South- East Asia countries.

In successful English teaching learning process, actually there are some factors that have been considered as significant factors. The factors are teachers, students, curriculum, materials, and learning facilities. From all factors above, currently attitude has recently become a considerable attention in a foreign language teaching process. As stated by Soleimani and Hanafi (2013), some variables such as attitude, orientation, motivation, and anxiety contribute to foreign language learning. Among these various factors, attitude toward language learning are considered as the key factors for the people to learn a language. It can be summarized that one part that can indicate the successful or unsuccessful learning of foreign language is students' language attitude. It is also as stated by Arifin (2012, p. 67), the students as foreign English learners are reminded to pay closely attention to attitude. Sholihah and Suharti (2015, p. 184) likewise stated that attitude plays the crucial role. In view of the findings, language attitude of students influence maintenance of Indonesian language. As of today, Aldosari (2014) states that the human attitude is made up of three components, which are shown the way the human think (cognitive domain), behave (behaviour domain), and feel (affective domain).

A study of language attitude is getting much attention for years since the study is one of the important topics of researches in some fields. As stated by Bohner and Dickel (2011) in McCoach, Gable, and Madura (2013), the study of attitude is one of the core topics in a research. They, then, further explain that attitude as "the most distinctive and indispensable concept in contemporary social psychology". Additionally, language attitude vary in nature. People show attitude of varying nature such as attitude to the variation of language, attitude to leaning foreign language, attitude to minority language and dominant language, attitude to foreign and second language, attitude to a specific language, etc. One of those varieties of specific attitude that have been attracting attention is attitude to foreign language in pedagogy process.

In Indonesia, attitude becomes a core attention in education. It is getting obvious since 2013, there have been some changes on curriculum previously named as School Based Curriculum into 2013 Curriculum emphasizing on students' character building which has one of important aspects. This term which is a basic competence grouping is about attitude.

Besides, Law 20 of 2003 on the Educational National System (UU Nomor 20 Tahun 2003 tentang Sistem Pendidikan Nasional) further explains that the curriculum development is organized in accordance with the level of education within the framework of the national unity of the Republic of Indonesia and takes the following into account: (a) the enhancement of faith and piety, (b) the enhancement of noble character, (c). the enhancement of learners' potential, intellect, and interests, (d) the diversity of the diversity of the region's potential environment, (e) demand for regional national development, (f) requirement of labour market, (g) development in science, technology, and arts, (h) religion, (i) the dynamic of global development, and (j) the national unit and nation's values. From the explanation above, it can also be concluded that attitude has been become a core attention in Indonesia education.

Despite the fact that Indonesia government strongly encourages the citizens to learning English and also the increasing popularity of this fast growing foreign language in Indonesia, there has been inadequate research to describe the attitude of Indonesian people towards this language and its learning. In fact, Lauder (2008) further explains that the big problem in Indonesia is a lack of research. Mostly, Indonesian people do not know what the situation of English is at many levels in Indonesia, whereas the demand for English is increasing. Hence, research of language attitude is important to be conducted. It can be concluded that by providing insight into 
attitude of learners in Indonesia towards English language will be expected to be able to contribute to an understanding of English learning and teaching in Indonesia, and add to the growing body of studies on spread of English in expanding circle countries where people speak English as a foreign language as stated by Kachru (1985a) that is mentioned by Kachru and Smith (2008).

Moreover, knowing about attitude is significant in pedagogical capital because language attitude is a part of important contributions of language teaching learning process. Understanding learners' foreign language attitudes is very important because it can obtain a useful insight which can be used to improve the quality of its teaching and learning pedagogy. As said by Barnes and Lock (2010), lecturers should understand their students' attitude in order to be responsive to their students' needs and enhance the success of students' learning. Therefore, research of language attitude also will give contributions for lecturers in teaching learning pedagogy. As stated by Gardner (cited in Melhim \& Rahman, 2009,p.3), attitude can express some important aspects of an individual's personality, such as to express who people are and what people believe in. Besides, Ukpong and George (2013) further stated that there was a relation between the English study time and the achievement of learning English.

In addition, studying language attitudes helps all stakeholders in different ways. Firstly, an investigation into students' attitudes is an effective way for which language teachers, education planners, syllabus designers, and researchers in order to obtain greater understanding into the language pedagogical process. Secondly, each student has different needs, beliefs, preferences, educational backgrounds, and learning styles. Those factors can lead different reaction in leaning language. In other words, the students have their own language attitudes towards English as a foreign language. Besides, they also have views on the English learning process.

Considering the above contents, the investigation of the language attitude of learners towards English language is important. In this case, this study also explores the factors that may influence their attitude, such as gender and length of the English study years.

The problem that can be formulated in this study as follow: (1) what are the language attitudes of undergraduate students of English education department towards English in English education department of Surakarta
Muhamamadiyah University? (2) Is there any difference in undergraduate students' language attitudes towards English across gender and length of the English study years in English education department of Surakarta Muhamamadiyah University?

\section{METHOD}

This research employed by a mixed methods research design to be a procedure for collecting, analysing, and mixing both quantitative and qualitative methods in a single study to understand a research problem. The basic assumption is that the uses of both quantitative and qualitative methods, in combination, provide a better understanding of the research problem and question than either method by itself. The quantitative method is used to analyse quantitative data by using questioners, then the qualitative method is used to analyse qualitative data by using interviews. In addition, this research uses descriptive method with a quantitative approach then. According to Sugiono (2013,p.21), descriptive statistics is statistics which is used to analyse data by describing or portraying data that have been collected without making any conclusion to generalization.

Creswell (2013) further explains that essentially a mixed methods approach is one in which the researcher tends to base knowledge claims on pragmatic grounds, such as consequence-oriented, problem-centred, and pluralistic. It employs strategies of investigation that involve collecting data either simultaneously or sequentially to best understand research problems. The data collection also involves gathering both numeric information as well as text information so that the final database represents both quantitative and qualitative information.

In addition, using the triangulation of research methods can provide better understanding of a research problem than either research approach alone. Quantitative research itself is an inquiry into an identified problem based on testing a theory, measured with numbers, and analysed using statistical techniques. The goal of quantitative methods is to determine whether the predictive generalizations of a theory hold true. By contrast, a study based upon a qualitative process of inquiry has the goal of understanding a social problem from multiple perspectives. Qualitative research is conducted in a natural setting and involves a process of building a complex and holistic picture of the phenomenon of interest. Therefore, whereas in 
the research, the researcher tried to use the mixed method in order to reveal depth in research result.

This research uses sequential procedures, in which the researcher seeks to elaborate on the findings of one method with another method. This research uses sequential explanatory. In this research design, the researcher used quantitative and qualitative method. Hence, concurrent triangulation which uses qualitative and quantitative research methods conducted together.

This research was conducted in English Education Department of Surakarta Muhammadiyah University in academic year 2015 in November 2015. The research location is in the English Education Department.

The population of this study is 762 undergraduate students of the English Education Department of Surakarta Muhammadiyah University in academic year 2015. There are 256 undergraduate students in the first year of their study, 271 students in second years of their study, and the third year students of their study are 235 .

In this research, a sample of 214 undergraduate students was selected by using a proportional stratified random sampling technique with 5\% level of significance from Nomogramin (Sugiono, 2013, p. 130).

Data collection for this study was approximately one and a half months. Researcher used concurrent nested design in which qualitative and quantitative data were collected concurrently. The instruments were concerned with undergraduate students' language attitudes towards English. The question items in questionnaire were in English and Indonesia. The reason is that to cope the misunderstanding when finishing the questionnaire. On the other hand, the open ended questions in questionnaire were written in English. The reason is the undergraduate students were adult learners have studied English generally from they were in junior high school. Therefore, it could not be difficult for them to understand and answer English questionnaires. Although, the open ended questions were in English, the researcher was in the class during the proses in which the respondents were answering their questionnaires. Hence, whoever wanted to question what they did not understand with the question items, they could ask the researcher directly for their clearer understanding of each item. Before distributing the questionnaires to the actual sample, the questions were first written in English and then were translated into Indonesia. The Indonesia translation was translated again into English to check the accuracy of the translation. After translation for the closed ended questions, the questionnaires were distributed to 214 students.

The respondents had to read each of the statements then they had to tick only one option for each item in the closed-ended questionnaires to reflect their language attitude toward English by using the scale that had been available. Besides, in the process of data collection, the researcher reminded the respondents that there is actually no right or wrong answer in order to the respondents can give their answers honestly.

After having a look at the completed questionnaires which consisted mainly of closed questions and open ended questions, some responses needed to be clarified, so the next step of data collection was conducting structured interviews with the respondents to elicit more explanations. Similar to the questionnaires, the interviews required the interviewees to clarify their language attitudes towards English. The interviewees' responses were recorded in sound recorder of hand phone during the interviews.

Despite the fact that the researcher used open ended questions in the questionnaires, using structured interview method for collecting qualitative data is also needed. As stated by Bryman (2008), self-completion questionnaire and structured interview are very similar methods of social research. Nevertheless, there are several disadvantages of the self-completion questionnaires in comparison the structured interview. Hence, to cope with the disadvantages of the selfcompletion questionnaires, the researcher conducted the structured interview. The interview method was also selected to offer deeper insights and additional information about language attitudes of the students.

The interview itself is exploratory in nature, in order to provide qualitative data for triangulation with the quantitative data. It was conducted at the same visit to the research site for quantitative data collection. According to Warren (2002) in Bryman (2008), for a qualitative interview study to be published, the minimum number of interviews required seems to be between twenty and thirty. It is inferred from the statement, twenty random respondents were interviewed for completing the data.

The interviews were conducted during the researcher's last visit to the campus. In conducting the interview, the interviewer explained to the respondents the purpose, scope, nature, and conduct of the interview. So that, the interviewee were left in no doubt as to what would happen 
during and after the interview processes. Moreover, the students' interviews consisted of some questions that are quite similar to the open ended questions in questionnaire with some additional questions to find out more information that might not appear from the questionnaires.

\section{FINDINGS AND DISCUSSION}

Results of the present study have indicated that most of the undergraduate students at English Education Department of Muhammadiyah University of Surakarta have different attitudes, in terms cognitive, behavioural, and affective aspects of language attitudes towards English. Moreover, based on the research result, gender and length of English study years affected the language attitudes of undergraduate students.

\section{Language Attitudes of Undergraduate Students towards English in terms of their Behavioural, Cognitive, and Emotional Aspects}

Based on the questionnaires and the respondents' comments, as well as the interview processes, the findings indicate that most of the undergraduate students in English Education Department of Muhammadiyah University of Surakarta have different attitudes, in terms cognitive, behavioural, and affective aspects of language attitudes towards English. The three main components of language attitudes are closely related to each other.

As shown in the research result above, there have been shown about each component of the language attitude. In general, the respondents' positive cognitive aspect of language attitude was high. The positive attitudes show on several cognitive attitudes of the respondents.

They claimed neutral attitude for it, although they studied English in English Education Department for their bachelor's degree. It means that they studied English not only for getting the bachelor degree, but also they strongly believed that they can create new thought by studying English. Besides, they thought that they can be more knowledgeable by studying English. They disagreed that studying English is a waste of time because they believed that English plays an important role for their life. They agreed that being good at English can help them study other subject. They also believed that studying English is important for their future career. The prestigious language status might be a reason of they though that they must study English. Furthermore, the language is the main tool for communication with people from other countries since the global status of English is partly due to the number of people who speak it. In other words, all interviewees believed that English symbolizes internationalization and plays a crucial role in international communication. They disagree that studying English is dull.

In other words, the undergraduate students in general had high positive cognitive attitudes towards English language. Most of them believed that English plays a crucial role in their future life. They considered English to be important for its usefulness in international communication and educational or career advancements. They were aware that the position of English in the world and also in Indonesia. Their belief and perceptions above can be concluded that their negative cognitive aspect of language attitude was low.

With the respondents' beliefs and perceptions, the undergraduate students showed their behaviours related to their cognitive attitudes. In this research, the undergraduate students had high positive conative attitudes towards English, and had neutral negative behavioural attitudes towards English. The respondents deal with their own way to behave and react in studying English. Most of respondents (in both questionnaire and interview) were shown that they like doing English spoken language skill. It made them active learners during English pedagogical process. Besides, they also like practicing English speaking with their friends because they had good relationships with the others. However, they like practising English, in fact their behaviour to read English textbook is neutral. As shown in the open ended questions on the questionnaire and interview results, they actually like doing literary skill not too much. The undergraduate students did not like reading or writing English much.

Furthermore, neutral negative attitude was shown in the research result. It is also correlated to the research result of the interview and openended questions on the questionnaire. Most of them also had different behaviours when facing English assignments. Some of them never put off to finish the assignments because of various reasons. On the other hands, some of them put off to finish the assignments with different reasons. Although, they ever put off to finish the assignments it does not mean they did not like English. In general, popular reasons why they put off to finish the assignments are (1) they felt lazy and bored to finish English assignments; (2) they 


\section{LingTera, 5 (1), 2018 - 15 \\ Setyo Wati}

had many duties of campus organizations which they join, so they occasionally forgot the assignments to be finished; (3) there were too many English assignments; (4) the assignments were too difficult to be done. Moreover, the interviewees who never put off to finish the assignments because they were aware of the assignments had many advantages to improve their language skills. Although, some of them sometimes did not understand the materials, the kept trying their best to study English. Then, it can be concluded that positive cognitive attitudes are related to the behavioural language attitudes of the undergraduate students.

Moreover, the affective language attitudes show that negative affective attitude of the respondents was low, and the positive attitude was medium (neutral). Their affective attitudes reveal some attitudes, such as they dislike whoever asking them to make an English conversation neutrally. Although, they slightly agreed to make an English conversation, studying English made them have good mood and they also like to answer English questions voluntarily in English class, regardless of whether they were right or wrong. Interesting result is that although they were eager beavers to study English, they were slight interested in English class and slight confident to speak English.

The further explanation why they had different feelings in speaking English is as follows: (1) their lack of English communication, (2) their self-nervousness to speak English, (3) their fearfulness in making mistakes. The following interview transcripts elaborate the points above. Although, they who were unconfident to speak English, they still kept trying to study English to overcome their weaknesses in speaking English. Besides, most of them practised many times to speak English in order to make them braver to communicate with the others, especially with English native speakers. Some speaking duties from their lecturer also contributed them to make them more confident in speaking English.

\section{Undergraduate Students' Language Attitudes across Gender}

The inferential statistical analysis was employed to answer the second question concerning the differences in the participants' language attitudes towards English across gender. The results of independent sample T-test illustrate the independent sample T-test analysis which was carried out to explore the probability of the difference in the participants' language attitudes towards English across gender. There was a slight difference among the gender groups. Furthermore, the T-test for Equality of Means was to examine the differences in the participants ${ }^{6}$ language attitudes due to gender variable.

From the output of SPSS program, it was shown that the p-value was 0.573 . It means that $\mathrm{p}$-value was greater than 0.05 . Hence, the $\mathrm{H}_{0}$ is accepted. It can be concluded that there is a statistically significant difference in the undergraduate students' language attitudes towards English across gender. Moreover, the inferential statistical analysis was employed that the mean score of language attitudes among male undergraduate students is 91.21 and standard deviation is 8.975. On the other hand, the mean score of language attitudes respectively among female undergraduate students is 90.51 and standard deviation is 7.599. These descriptive results show that the attitudes of male undergraduate students towards English are higher than female ones. It means that there is a rejection of the null hypothesis, because there is a significant difference between male and female undergraduate students towards English.

\section{Undergraduate Students' Language Attitudes by Length of English Study Years}

The statistical analysis was employed to answer the third research question concerning the differences in the participants' language attitudes towards English by length of English study years. The research result shows that the language attitudes mean score among first, second, and third year in learning English are 91.51 (SD= 6.402), $90.07 \quad(\mathrm{SD}=8.822), \quad$ and 90.55 $(\mathrm{SD}=8.536)$. It can be seen that there is a difference among the three groups in their language attitude towards English. The first year of undergraduate students showed a slightly higher language attitudes compared with both second and third years of undergraduate students.

Furthermore, the output of homogeneity of variance test was conducted to determine the assumption of equal variances among the three groups of study year variable. The assumption of equal variances is met. It means that the data were homogenous. The analysis of One-way ANOVA was utilized to illustrate the differences in the participants' attitudes towards English regarding their year in learning English. 
Table of SPSS output of ANOVA Language Attitude

\begin{tabular}{lrrrrr}
\hline & $\begin{array}{c}\text { Sum of } \\
\text { Squares }\end{array}$ & Df & $\begin{array}{c}\text { Mean } \\
\text { Square }\end{array}$ & F & Sig. \\
\hline $\begin{array}{l}\text { Between } \\
\text { Groups }\end{array}$ & 79.839 & 2 & 39.920 & .625 & .536 \\
$\begin{array}{l}\text { Within } \\
\text { Groups }\end{array}$ & 13483.021 & 211 & 63.901 & & \\
Total & 13562.860 & 213 & & & \\
\hline
\end{tabular}

The SPSS output demonstrates that there is a difference in the undergraduate students' attitudes towards English due to the year in learning English variable as the $\mathrm{p}-$ value is greater than $0.05(\mathrm{p}=0.536>0.05, \mathrm{~F}=0.625)$. Based on the ANOVA results, it can be concluded that there is a significant difference in the undergraduate students' language attitudes towards learning English language across the year in learning English.

\section{CONCLUSION}

Based on the research result and discussion by combining qualitative and quantitative data in Chapter IV, the conclusions in the study are drawn as the following points.

The undergraduate students have different attitudes, in terms cognitive, behavioural, and affective aspects of language attitudes towards English. The language attitudes of male and female students of undergraduate students were captured as same level category in cognitive, behavioural, and affective aspects. Firstly, both male and female respondents' positive cognitive aspect of language attitude was high. On the other hand, the negative cognitive aspect of language attitude was low. In other words, undergraduate students, in general hold positive cognitive attitude toward English. They consider that English is important for its usefulness in international communication and educational as well as career advancements. Briefly, most of respondents' obvious positive language attitude towards English can be concluded that they were well aware of importance of English.

Secondly, both male and female participants had high positive behavioural aspect of language attitude towards English, and medium level for the negative attitudes of behavioural aspect. It means that undergraduate students generally hold positive behavioural attitude toward English. They have positive behavioural language attitudes to study English in the class. Although, they hold positive conative attitude in the class, some of them occasionally put off to finish their English assignments. Besides, they also felt not relaxed enough to read English textbook, because most of them preferred doing spoken language skill to literacy skill.

Thirdly, both male and female participants hold the high positive affective attitude towards English. On the other hand, the negative attitude of affective aspect was medium. It shows that the participants hold positive emotional attitude towards English, and the negative attitude of affective aspect was medium. However, they were interested in studying English, some of them felt nervous in English class, so that some of them had a little in English class.

In addition, the attitudes of male undergraduate students towards English are slightly higher than female ones. It means that there is a rejection of the null hypothesis, because there is a significant difference between male and female undergraduate students towards English. There is a difference among the three groups in their language attitude towards English. The first year of undergraduate students showed a slightly higher language attitudes compared with the other two groups.

In light of the contribution of this study presented above, this section discusses the implications for the undergraduate students and for the English lecturers. Investigating language attitude of undergraduate students is significant in language pedagogy process because language attitude is a part of important contributions of language teaching learning process. The attitude is helpful to successful language learning, but it depends on the language attitude result of the way the learners feel, believe, and behave towards the object of study. If the learning situation is a cause of negative attitudes for the learners, it likely makes the learners develop the negative attitudes also towards English. Furthermore, the learners' interpretations about the target language can also have determinant in the learners' language attitudes towards English. Therefore, investigating language attitudes of undergraduate students as foreign language learners is essential in the process of foreign language learning. Language learners and lecturers (teachers), for example, are people whose attitudes can bear effective English language learning. The language learners have to understand what they have to do in their study by investigating the language attitudes. Understanding learners' foreign language attitudes is important because it can obtain a useful insight which can be used to improve the quality of its teaching and learning pedagogy. By probing into gender attitudinal difference, language instruct- 
ion can be geared up based on the learner gender's interest. As far as gender of both female and male is concerned, there are differences shown in the learning process. The results from this study imply that English teacher or lecturers should not exercise any bias or prejudice on gender bases and they should work to improve learners' attitudes towards the target language.

Moreover, the findings have significant implications for English language pedagogy considering the fact that the results of this study exhibited positive attitudes towards English language. Thus it is recommended that this positive attitude of the undergraduate students should be exploited properly to enhance and maintain their inclinations in this regards.

Having conducted the research, the researcher would like to give some suggestions as follows. (1) The most important suggestion is addressed to the undergraduate students. They should realize that their language attitude define whether their language learning is successful or not. (2) Attitudes of lecturers (teachers) towards foreign language learners can also affect the learning which takes place. The reason is that language learning is not only cognitive stage (where the learners are involved in conscious activities resulting in knowledge), but also affective factors are important and they should pay attention to them. Hence, the lecturers (teachers) of English can create a good and trustful atmosphere for their English classrooms, based on the investigation of their students' language attitudes. (3) This study is about an effort to investigate the language attitudes of the undergraduate students in one college. The other researchers are suggested to develop their research in the larger area, so the research result can be generated, and then the participants of the research can represent all undergraduate students in Indonesia. Moreover, the other researchers also can conduct language attitude study within a longer time frame in order to capture not only the descriptions of the language attitudes of participants, but also capture any change in language attitudes. (4) The education institutions which provide English teaching learning should review the content and the design of the teaching learning pedagogy to meet the needs and the interest of the students. They are recommended to consider that English foreign language learners have different perceptions about learning language due to their differences regarding gender and their years of study. Hence, taking all these issues into account will be essential to see something different concerning the activities, contents, topics, teaching practices, and the others.

\section{REFERENCES}

Aldosari, H.S. (2014). The entwined effects of attitude, motivation and gender on EFL learning: A correlation study. Journal of Studies in Literature and Language, 8 (1), $1-5$.

Arifin, W.L. (2012). The eddects of the text-based vocabulary teaching model on the communicative vocabulary competence of the TBI fourth semester Students of STAIN Salatiga. Thesis the degree of M.A. Applied Linguistics (English Language), unpublished thesis, Yogyakarta State University, Yogyakarta.

Barnes, B. D., \& Lock, G. (2010). The attributes of effective lecturers of English as a foreign language as perceived by students in a Korean university. Australia Journal of Teacher Education, 35(1).

Bryman, A. (2008). Social research methods (rev. ed.). New York: Oxford University Press.

Creswell, J.W. (2013). Research design: qualitative, quantitative, and mixed methods approaches. London: SAGE Publications, Inc.

Jenkins, J. (2014). English as a lingua franca in the international university: The politics of academic English language policy. Oxford: Routledge.

Kachru, Y. \& Smith, L.E. (2008). Cultures, contexts, and world Englishes. New York: Routledge Taylor and Francis Group.

Lauder, A. (2008). The status and function of English in Indonesia: A review of key factors. Makara, Social Humaniora, 12(1), 9-20.

McCoach, D.B., Gable, R.K., \& Madura, J.P. (2013). Insrument development in the affective domain. New York: Springer.

Melhim, A. \& Rahman, A. (2009). Attitudes of Jordanian college students towards learning English as a foreign language. College Student Journal. Online. Accessed on December 15, 2015 from http://web.ebscohost.com.

Republik Indonesia. (2003). Undang- undang RI nomor 20, tahun 2003, tentang sistem pendidikan Indonesia. 


\section{LingTera, 5 (1), 2018 - 18}

Setyo Wati

Sholihah, R.A., and Suharti. (2015). Sikap dan pemertahanan bahasa Indonesia siswa kelas X SMA Internasional Budi Mulia Dua Yogyakarta. Lingtera. Accessed on January 29,2016,from http://journal.uny.ac.id/index. php/ljtp.

Soleimani, H., \& Hanafi, S. (2013). Iranian medical students' attitudes towards English language learning. International Research Journal of Applied and Basic Sciences. Sciences Explorer Publications.

Sugiono. (2013). Metode penelitian kombinasi (mixed methods). Bandung: Alfabeta.
Yusny, Rahmat. (2014). ELT in Indonesian Context: Issues and Challenges. Englisia, 1(1), 81-99.

Ukpong, D.E., and George, I.N. (2013). Length of study-time behaviour and academic achievement of social studies education students in the university of Uyo. International Education Studies, 6 (3), 172-178.

United Nations Educational, Scientific, and Cultural Organization. (2003). Education in multilingual world (UNESCO Education Position Paper). France: UNESCO. 